Journal of Social Sciences 5(4): 329-331, 2009

ISSN 1549-3652

(C) 2009 Science Publications

\title{
Community Learning Center for Building Alternative Learning among the Youth
}

\author{
${ }^{1}$ Sampan Rittidet ${ }^{2}$ Sombat Rittidet ${ }^{3}$ Prasopsuk Rittidet and ${ }^{4}$ Winyoo Sata \\ ${ }^{1}$ Department of Mechanical Engineering, Mahasarakham University, Thailand, 44150 \\ ${ }^{2}$ Department of Curriculum and Instruction, \\ Rajabhat Mahasarakham University, Thailand, 44000 \\ ${ }^{3}$ Project Researcher of Phoo Tuad Kru Sing Rittidet Community Learning Center, \\ Thailand, 44000 \\ ${ }^{4}$ Department of Public Administration and Public Affairs, \\ Bandit Boriharnthurakit College, Thailand, 40000
}

\begin{abstract}
Problem statement: The research question arose from the youth's problems, such as, playing truants, motorcycle racing and drug taking. The students, primary and secondary school levels, did poorly in classes or dropped out from school. The Thai society, therefore, took in poorly-prepared youth. The study aimed at building an alternative learning center for the Thai youth so that they could use their free time efficiently. The community learning center was located at No. $1 \mathrm{Mu} 6$, Ban Koodkan, Tambon Nong No, Amphoe Muang, Mahasarakham. Approach: The research was qualitative using documentary studies, interviews and focused group discussions. The student sample were primary and secondary, age 8-25 year school-drop outs 5 parents, 2 administrators of the community learning Center, 2 teachers and 3 community leaders. The data were analyzed descriptively. Results: The study found that the community learning center was established by Rittidet family members. Mr. Sing Rittidet's sons and daughters pushed their father's ideology in giving knowledge back to community. The learning center was built on the Rittidet's land for the benefit of all people at Ban koodkan. The goal was to assist the students, primary and secondary school level, to accomplish alternative learning using their free time. As a social-based learning center, the close relationship among students, parents, folk teachers was established. The students had an opportunity to develop self-help using various activities provided in and outside their community learning center. The students' occupational skills were assisted by the Rittidet people. Conclusion: The learning center, therefore, built a suitable condition for living community, warm families and well behaved youth. The center was used to suit individual needs, such as, a happy living, alternative learning and building own future.
\end{abstract}

Key words: Community learning center, building alternative learning among the youth of northeast Thailand, youth's problem

\section{INTRODUCTION}

The Thai youth situation, as reflected last year, indicated various risks caused by families, media, living areas and poor quality education. The teacher-based center alone introduced the school children with contents that were not familiar to them ${ }^{[1]}$. The school Children, who wanted to take responsibility for making their nation strong, should learn to be patient, honest, well disciplined, keep and love the Thai cultural personality ${ }^{[2]}$. suggested the Thai society should have fine quality of families, living environment and education. It was important that the children living environment be improved using the close cooperation between the people who lived inside and outside of each community. The philosophy guided the activities carried out at community learning center, out at \# $1 \mathrm{Mu}$ 6, Ban koodkan, Tambon Nong No, Amphoe Muang, Maha Sarakham was to give knowledge back to society and integrate with the idea of having the children and adults as leading and backing up force respectively.

\section{MATERIALS AND METHODS}

The research was carried out using qualitative research. The data were collected from 27 sample using documentary studies and fieldwork. The instruments used interviews and focused-group discussions. The analysis and report were done descriptively.

Corresponding Author: P. Rittidet. Faculty of Education, Rajabhat Mahasarakham University, Thailand Tel: 66-43981257 Fax: 66-43981257 


\section{J. Social Sci., 5(4): 329-331, 2009}

\section{RESULTS}

Building a community learning center at No. $1 \mathrm{Mu}$ 6, Ban koodkan, Tambon Nong No, Amphoe Muang, Maha Sarakham was to give the knowledge back to society initiated by the head of Rittidet clan who was then a former primary school teacher. His sons and daughters followed through their father's ideology by building a community learning center on a piece of their own land.

The learning center assisted children and youth in learning an their own pace and circumstances. The practice and ideology certainly corresponded to the Thailand's educational philosophy concerning their choices of learning and occupations. The community had resource-persons who were well-known for various specialties such as, agriculture, basketry, folk performance and silk weaving. The resource-persons taught several places, family and community were included $^{[3]}$.

Factors initiated the youth into using free time for alternative learning: After the construction of the school building was finished, the Rittidet clan the announcement for enrolment was made. The boys and girls, who were 8-25 year old, had behavioral tags with them. Some were school-drop outs. The others poor grades, were drug addicted, creative or school-loving goers. Factors initiated their alternative learning were as follows:

Community learning center was social-oriented context: The activities, carried out at the community learning center, were possible due to close cooperation with various people, namely, parents, teachers, folk teachers, NGOS and the students themselves. The students, were divided into small groups, set up their own corner so they could study Thai, English, mathematics, arts, games, folk music, or do meditation. They could also do outdoor-activities, such as, playing with a swing or a cot, playing football, trakraw (a ball made of woven rattan), jumping rope or fish trapping. Some students could watch the fireflies in the backyard. The students were allowed to take part in all activities beginning from 9 o'clock to 8 pm without any charge. The teachers and parents were ready to work or give some advice. They came to the learning center with their mind open. They were ready to spend their free time making new friends or learning new things.

The community experienced more peaceful life and environment due to alternative learning and choices they chose to suite their own needs and interest.
Self-help learning: As the community learning center at Ban koodkan, Tambon Nong No, Amphoe Muang, Maha Sarakham Province is built, owned and maintained by private ownership of the Rittidet family members, the students "parents, community leaders, folk teacher and the students themselves came together to create learning environment and improve the students intellectually, physically, emotionally and socially. Each student chose an activity that suited his or her own interest. It was like building one's own future. Each activity may lead to one's occupation. It was a matter of choice of an individual as well as groups of people $\mathrm{e}^{[4]}$.

Learning professional skills with various activities: The activity that captured the youth's interest the most was the applied pong lang music. The music instruments included were pong lang, whote, khaen, rammana, ching, chab, pin and saw. The music lessons were done differently. They could be done one to one basis or friends taught friend method. The students of risk and normal groups set up a folk music band. The often put on stage-shows on various occasions, such as, Thai culture and community, Against drug day-world. The students made some extra money while going to school. Their parents were proud of them. The audience all accepted the talents of the youth. Their use of free time helped to transfer folk culture. The folk music teachers were best social asset. A lot of hands and effort helped the youth's dreams possible. The folk music brought friendship among children. They grew up with love, understanding life and cultural conservation ${ }^{[5]}$.

Adult Learning with good heart and energy: Beginning with the Rittdet family and clan, the partnership of the learning center were parents, community leaders, folk teachers of various knowledge fields and house wife-groups. They were all good hearted people. They assisted their child or children to learn on their own pace and interest. They learned how to put things from inside and outside together and then made them their own knowledge and understanding. Our country needed and still does, the learning and exchanging processes ${ }^{[5]}$.

\section{CONCLUSION}

This case study was done on behalf of the Rittidet family and élan, devoted and honor to the head of the family, Mr. Sing Rittidet. The purpose was to assist the students at risk and normal children. The coming together of the 2 groups of children opened up new learning opportunities. Such a social innovation led to 
youth's problems solving. Learning activities were created to suit their own needs. It was like a rehabilitation of education of people by the people for their present and future circumstances, especially their occupations'

The learning center at Ban Koodkan, Tambon Nong No, Amphoe Muang, Maha Sarakham province brought a lot of good things to the community, such as, good human relationship, self understanding, choices of learning to suit one's interest of learning and build one's own future occupation. All was possible due to Mr. Sing Rittidet's philosophy of giving back knowledge to society.

\section{ACKNOWLEDGEMENT}

The researchers express their sincere appreciation for all of support provided and the referees for their helpful comments.

\section{REFERENCES}

1. Prawese Wasi, 2006. Knowledge Management: Humanities Freedom Process Though capacity, Freedom and Happiness. 1st Edn., GreenIntellectual Press, ISBN: 978-974-8290-82-9, pp: 21.
2. Nakhonthap, A., 2006. Thai children in Thai Cultural Dimension. 3rd Edn., The Veteran Welfare Organization Press, ISBN 974-9681-25-8, pp: 209.

3. Jammarik, S., 1998.Thinking Base for New Choice of Thailand. 1st Edn., Amarin Printing and Publishing Ltd Press, ISBN: 974-272-313-3, pp: 217.

4. Chareonwongsak, K., 2003. Future Thinking. 1st Edn., Success Media Ltd Press, ISBN: 974-846-355-9, pp: 133-191.

5. Kaewthep, K., 2004. Communication for Beautiful World: The lesson from Communication to Manage the Environment in Community. $1^{\text {st }}$ Edn., Seven Printing Group Ltd. Press, ISBN: 974-941 98-63, pp: 280. 